\title{
The Impact of Lockdown on eBC Mass Concentration over a Semi-arid Region in Southern India: Ground Observation and Model Simulations
}

\section{Surya Nagi Reddy Palle ${ }^{\dagger}$, Chakradhar Rao Tandule ${ }^{\dagger}$, Raja Obul Reddy Kalluri, Balakrishnaiah Gugamsetty, Rama Gopal Kotalo*, Lokeswara Reddy Thotli, Bhavyasree Akkiraju, Siva Sankara Reddy Lingala}

Aerosol and Atmospheric Research Laboratory, Department of Physics, Sri Krishnadevaraya University, Anantapur, Andhra Pradesh, India

\section{ABSTRACT}

In the present study, we focused on the impact of lockdown on black carbon (eBC) mass concentrations and their associated radiative implications from $01^{\text {st }}$ March to $30^{\text {th }}$ June 2020 , over a semi-arid station, i.e., in the district of Anantapur in Southern India. The mean eBC mass concentration was observed before lockdown (01 $11^{\text {st }}-24^{\text {th }}$ March 2020) and during the lockdown $\left(25^{\text {th }}\right.$ March-30 th June 2020) period and was about $1.74 \pm 0.36$ and $1.11 \pm 0.14 \mu \mathrm{g} \mathrm{m}^{-3}$, respectively. The sharp decrease ( $35 \%)$ of eBC mass concentration observed during the lockdown (LD) period as compared with before lockdown (BLD) period, was mainly due to the reduction of anthropogenic activities and meteorology. Furthermore, during the entire LD period, the net composite forcing at the top of the atmosphere (TOA) and at the surface (SUR) varied from -4.52 to $-6.19 \mathrm{Wm}^{-2}$ and -22.91 to $-29.35 \mathrm{Wm}^{-2}$, respectively, whereas the net forcing in the atmosphere (ATM) varied from 17.27 to $23.16 \mathrm{Wm}^{-2}$. Interestingly, the amount of energy trapped in the atmosphere due to eBC is $11.19 \mathrm{Wm}^{-2}$ before LD and $8.56 \mathrm{Wm}^{-2}$ during LD. It is concluded that eBC contributes almost $43-50 \%$ to the composite forcing. As a result, the eBC atmospheric heating rate decreased significantly (25\%) when compared to before lockdown days to lockdown days.

Keywords: COVID-19, Equivalent black carbon, Fossil fuel, Radiative forcing, Semi-arid

\section{INTRODUCTION}

In terms of urbanization and population, India is one of the fastest-growing countries in the world. Being exceedingly vulnerable to air quality, it is a well-known global hotspot of air pollution which regularly severe. A recent study by Thomas et al. (2019), over the Indian region showed that the number of hazy days increases at $\sim 2.6$ days per year according to the biomass burning activities. In this situation, the World Health Organization (WHO) declared coronavirus disease 2019 (COVID-19) as a pandemic due to widespread global infection with its first outbreak in Wuhan, Hubei, China. Globally, as of $5^{\text {th }}$ July 2021, there have been 183.37 Million confirmed cases of COVID-19, including 3.97 Million deaths, resulting in lockdown in many countries worldwide. In India, the first COVID-19 positive confirmed case was reported on $30^{\text {th }}$ January 2020 in India's Southern state, Kerala (Prasad et al., 2020). Henceforth, the number of confirmed COVID19 positive cases closed at 500; the first nationwide lockdown (named Janata Curfew) for fourteen hours was on $22^{\text {nd }}$ March 2020. This curfew was imposed suspending passenger travel both by air and on road, except essential sectors in the entire country. The rules framed by the government resulted in the reduction of human activities during the COVID-19 pandemic which impacted the air quality and helped in improving/understanding the air quality. Therefore, it provided an excellent opportunity for the government to implement a strategic plan focused on 
emphasizing multi-pollutant emission reductions and overall air pollution-related risk.

Investigations on air quality over Indian regions during this unprecedented lockdown showed a significant improvement in air quality (Chauhan and Singh, 2020; Jain and Sharma, 2020; Sarfraz et al., 2020; Kalluri et al., 2021). The parameters used by the investigators in the above-said investigations in quantifying the air quality are particulate matter (PM), nitrogen oxides $\left(\mathrm{NO}_{2}\right)$, sulfur dioxide $\left(\mathrm{SO}_{2}\right)$, ozone $\left(\mathrm{O}_{3}\right)$, carbon monoxide $(\mathrm{CO})$, and meteorological parameters. For example, Sharma et al., 2020 reported a reduction of $43 \%$ in $\mathrm{PM}_{10}, 31 \%$ in $\mathrm{PM}_{2.5}, 18 \%$ in $\mathrm{NO}_{2}$, and $10 \%$ in $\mathrm{CO}$, during the lockdown period compared to the previous years. On the other hand, negligible changes in $\mathrm{SO}_{2}$ and growth in $\mathrm{O}_{3}$ by $17 \%$ are seen over India. Hence, there was a unique prospect to retrieve the anthropogenic interference on air quality aspects from the local to the global scales during the lockdown situation.

One of the essential constituents of particulate matter is equivalent black carbon (eBC). The incomplete combustion of fossil fuels and biomass burnings are the primary sources of eBC aerosols in the atmosphere (Li et al., 2020; Petzold et al., 2013). eBC is a graphitic form of carbon particles with unique physical properties and can impact regional air quality (Kaur et al., 2020). Due to its absorbing nature in short-wave and long-wave radiation regions, it has tremendous climate implications (IPCC, 2013), especially over south Asia where absorbing aerosols abundance is high (Fan et al., 2021; Shalini et al., 2020; Kalluri et al., 2020b; Reddy et al., 2019). Hence, eBC has considered the second most potent climate forcing agent between carbon dioxide and methane (Gogoi et al., 2019; Jacobson, 2001). Absorbing aerosols like eBC aerosols can significantly heat the atmosphere and cool the surface (Kalluri et al., 2016, 2020a) also heat the surface (for example, eBC on snow (Kang et al., 2020)), resulting in a net positive forcing on Earth-atmospheric system (Gogoi et al., 2017). Keeping this in view the eBC aerosols and radiative forcing impact due to the COVID-19 lockdown from $25^{\text {th }}$ March to $20^{\text {th }}$ June 2020 and the similar data from the corresponding dates of the years from 2016 to 2019 over a semi-arid location, Anantapur has been reported and also presented in Table 1.

\section{SITE DESCRIPTION AND METHODOLOGY}

\subsection{Site Description}

This study analyses the impact of social and travel lockdown on aerosol properties over Anantapur, semi-arid, rain shadow Rayalaseema region in the peninsular Indian state of Andhra Pradesh. The observational site (Department of Physics, Sri Krishnadevaraya University) in Anantapur district is situated on the southern edge of the Anantapur town, as shown in Fig. 1. The observational site is approximately $10 \mathrm{~km}$ away from the city's centre, situated beside the national highway 42 (Anantapur-Chennai) and just $7 \mathrm{~km}$ away from the national highway 44 (Hyderabad-Bangalore). Additionally, the observational site is close to the railway route connecting Bangalore and other north Indian megacities. This observation site experiences frequent droughts and the second-lowest rainfall in India. The southwest monsoon contributes $>60-70 \%$ of the total rainfall, and the average rainfall is only $\sim 150 \mathrm{~mm}$ during the northeast monsoon period (Raja Obul Reddy et al., 2016). The possible aerosol sources are present at this site during the summer (March-May) including agricultural burning activites, fossil fuel burning activities, and transported/windblown dust from north-western winds (Kalluri et al., 2017; Gopal et al., 2014, 2015, 2016). Domestic burning is the main aerosol source in winter (December-February) (Gopal et al., 2017; Lingaswamy et al., 2017; Kalluri et al., 2016).

Table 1. eBC mass concentrations during before lockdown and during lockdown periods for the years $2016-2020$.

\begin{tabular}{lllllll}
\hline & 2016 & 2017 & 2018 & 2019 & Avg (2016-2019) & 2020 \\
\hline BLD & $2.23 \pm 0.36$ & $2.07 \pm 0.54$ & $2.30 \pm 0.23$ & $2.33 \pm 0.85$ & $\mathbf{2 . 2 3} \pm \mathbf{0 . 1 1}$ & $1.74 \pm 0.37$ \\
LDP1 & $2.27 \pm 0.43$ & $2.69 \pm 0.60$ & $2.50 \pm 0.42$ & $2.16 \pm 0.66$ & $\mathbf{2 . 4 0} \pm \mathbf{0 . 2 3}$ & $1.54 \pm 0.36$ \\
LDP2 & $1.93 \pm 0.39$ & $2.23 \pm 0.61$ & $1.97 \pm 0.36$ & $2.07 \pm 0.75$ & $\mathbf{2 . 0 5} \pm \mathbf{0 . 1 3}$ & $1.59 \pm 0.20$ \\
LDP3 & $1.35 \pm 0.25$ & $1.62 \pm 0.29$ & $1.37 \pm 0.28$ & $1.61 \pm 0.31$ & $\mathbf{1 . 4 8} \pm \mathbf{0 . 1 4}$ & $1.07 \pm 0.19$ \\
LDP4 & $1.04 \pm 0.33$ & $1.47 \pm 0.44$ & $1.50 \pm 0.23$ & $1.44 \pm 0.41$ & $\mathbf{1 . 3 6} \pm \mathbf{0 . 2 1}$ & $0.73 \pm 0.11$ \\
LDP5 & $1.27 \pm 0.13$ & $0.84 \pm 0.12$ & $0.90 \pm 0.16$ & $1.13 \pm 0.28$ & $\mathbf{1 . 0 3} \pm \mathbf{0 . 2 0}$ & $0.47 \pm 0.07$ \\
\hline
\end{tabular}




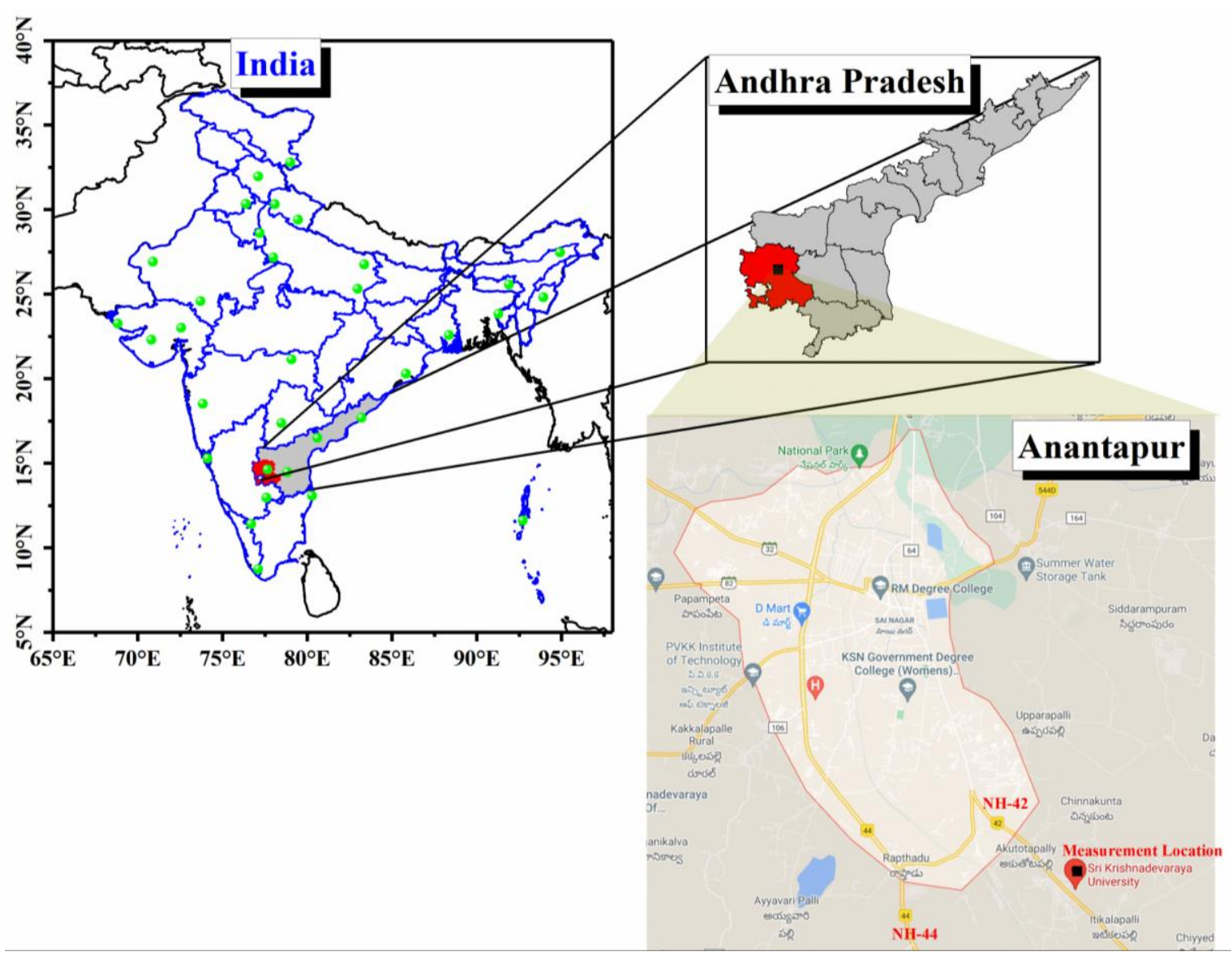

Fig. 1. Map of India showing various observational site (green circles) under ISRO-ARFI Project in which the present study location of Anantapur, Andhra Pradesh, and Google map showing the Department of Physics, Sri Krishnadevaraya University campus (Measurement Location) is highlighted.

The government of India imposed lockdown for more than two months with several relaxations in different phases. The timeline of the lockdown with restrictions and relaxations is given in Table 2 . These phases are namely before lockdown ( $01^{\text {st }}$ March-2 $4^{\text {th }}$ March), henceforth termed as BLD (24 days); lockdown 1.0 (LDP1; 21 days) from 25 $5^{\text {th }}$ March to 14 ${ }^{\text {th }}$ April; lockdown 2.0 (LDP2; 19 days) from $15^{\text {th }}$ April to $03^{\text {rd }}$ May; lockdown 3.0 (LDP3; 14 days) from $04^{\text {th }}$ May to $17^{\text {th }}$ May; lockdown 4.0 (LDP4; 14 days) from $18^{\text {th }}$ May to $31^{\text {st }}$ May; lockdown 5.0 (LDP5; 30 days) from $01^{\text {st }}$ June to $30^{\text {th }}$ June; the entire lockdown period (LD; 98 days) from $25^{\text {th }}$ March to $30^{\text {th }}$ June (LD considered as the mean for all the lockdown phases).

\subsection{Meteorology}

Meteorological conditions play a crucial role while discussing variations of aerosols at a particular site. The surface meteorological parameters [viz., temperature ( $\mathrm{T}$ in $\left.{ }^{\circ} \mathrm{C}\right)$, relative humidity $\left(\mathrm{RH}\right.$ in \%), wind speed (WS in $\mathrm{m} \mathrm{s}^{-1}$ ), and wind direction (WD in $\left.{ }^{\circ}\right)$ ] have been measured on a dayto-day basis at the observational site by employing Automatic Weather Station (AWS) (Campbell Scientific, made in Canada). Fig. 2 shows the day-to-day variation of air temperature, relative humidity, wind speed, and wind direction during the study period. The daily mean surface air temperature varied in the range of $28-38^{\circ} \mathrm{C}\left(29-37^{\circ} \mathrm{C}\right)$, whereas $\mathrm{RH}$ varied in the range of $21-$ 73\% (18-65\%) during 2020 (2019). The winds are mostly from the southwest, with a maximum wind speed of $\sim 7 \mathrm{~m} \mathrm{~s}^{-1}$ during both years. Thus, the meteorological conditions during both years almost resemble the same except in magnitude.

\subsection{Instrumentation}

Simultaneous eBC mass concentration measurements and spectral aerosol optical depths (AODs) 
Table 2. Detailed timeline of the lockdown with restrictions, relaxations, and the number of reported COVID-19 positive cases in India.

\begin{tabular}{|c|c|c|c|c|}
\hline S.No. & Timeline Phase & Period & Restrictions/Relaxations & $\begin{array}{l}\text { \# of COVID-19 positive } \\
\text { cases in India* }\end{array}$ \\
\hline 1 & $\begin{array}{l}\text { Before Lockdown } \\
\text { (BLD) }\end{array}$ & $\begin{array}{c}01^{\text {st }} \text { March-24 } \\
\text { March } 2020\end{array}$ & No restrictions & 445 \\
\hline 2 & $\begin{array}{l}\text { Lockdown } 1.0 \\
\quad \text { (LDP1) }\end{array}$ & $\begin{array}{l}25^{\text {th }} \text { March-14 } \\
\text { April } 2020\end{array}$ & $\begin{array}{l}\text { Nearly all services (except emergency services) and } \\
\text { factories were suspended. The transport of } \\
\text { essential goods through rail and road. }\end{array}$ & 10,817 \\
\hline 3 & $\begin{array}{l}\text { Lockdown } 2.0 \\
\quad(\text { LDP2) }\end{array}$ & $\begin{array}{l}15^{\text {th }} \text { April-03 }{ }^{\text {rd }} \text { May } \\
2020\end{array}$ & $\begin{array}{l}\text { Same restrictions as Lockdown } 1.0 \text { but with } \\
\text { conditional relaxation promised after } 20 \text { April } \\
\text { 2020. Permit for Agricultural businesses, as well } \\
\text { as shops selling farming supplies, cargo vehicles, } \\
\text { public works programs with instructions to } \\
\text { maintain social distancing, banks, and } \\
\text { government centers distributing benefits. }\end{array}$ & 31,288 \\
\hline 4 & $\begin{array}{l}\text { Lockdown } 3.0 \\
\quad \text { (LDP3) }\end{array}$ & $\begin{array}{l}\text { 04 } \\
\quad 2020\end{array}$ & $\begin{array}{l}\text { Normal movement is permitted in green zones (No } \\
\text { positive cases) with buses limited to } 50 \% \\
\text { capacity. Orange zones (fewer positive cases) } \\
\text { would allow only private and hired vehicles but } \\
\text { no public transportation. The red zones (high } \\
\text { positive cases and a high doubling rate) would } \\
\text { remain under lockdown. }\end{array}$ & 52,920 \\
\hline 5 & $\begin{array}{l}\text { Lockdown } 4.0 \\
\text { (LDP4) }\end{array}$ & $\begin{array}{l}18^{\text {th }} \text { May-31 } 1^{\text {st }} \text { May } \\
\quad 2020\end{array}$ & $\begin{array}{l}\text { Buses, auto-rickshaws, cabs can operate; Metro, air } \\
\text { and rail services remain suspended, except those } \\
\text { allowed with special permits; All shops, except } \\
\text { those in malls and containment zones, can open; } \\
\text { Restaurants can function, but only for take- } \\
\text { away; Night curfew from 18:00 to 07:00 IST for } \\
\text { non-essential services; Schools, colleges, malls to } \\
\text { remain shut; Religious, political gatherings } \\
\text { prohibited; Weddings cannot have more than } 50 \\
\text { guests and funerals not more than } 20 \text {. }\end{array}$ & 94,949 \\
\hline \multirow[t]{2}{*}{6} & $\begin{array}{l}\text { Lockdown } 5.0 \\
\quad \text { (LDP5) }\end{array}$ & $\begin{array}{l}01^{\text {st }} \text { June }-30^{\text {th }} \text { June } \\
\quad 2020\end{array}$ & $\begin{array}{l}\text { The reopening was planned in three phases. The } \\
\text { first phase was implemented on } 8^{\text {th }} \text { June to } \\
\text { reopen shopping malls, religious places, hotels, } \\
\text { and restaurants; Large gatherings are still } \\
\text { banned; no restrictions on inter-state travel; } \\
\text { night curfews from 21:00 to 05:00 IST. }\end{array}$ & $4,14,802$ \\
\hline & & & Total positive cases: & $\begin{array}{l}6,05,221 \\
\left.\text { (As on } 30^{\text {th }} \text { June, } 2020\right)\end{array}$ \\
\hline
\end{tabular}

\footnotetext{
* Data extracted from https://www.covid19india.org/
}

have been carried out regularly by deploying a seven-channel Aethalometer and five-channel MICROTOPS-II Sunphotometer, respectively. In the present study, quality-controlled data sets have been used for the respective lockdown phases.

The employed MICROTOPS-II Sunphotometer measures the intensity of direct solar irradiance at five narrow-band spectral channels centred at 380, 500, 870, 936, and $1020 \mathrm{~nm}$ through optical collimators with a full field view of $2.5^{\circ}$. The spectral AOD and total columnar water vapour content are the salient parameters in the sunphotometer determined based on the BougherLambert-Beer law. Further details of the instrument, like working principle, theory, data analysis, and calibration techniques, have been published elsewhere (Ichoku et al., 2002; Hussain et al., 2018). Sunphotometer data is not accessible after $01^{\text {st }}$ May 2020 due to unfavourable sky conditions.

Measurements of eBC aerosol mass concentration have been carried out using a seven-channel 

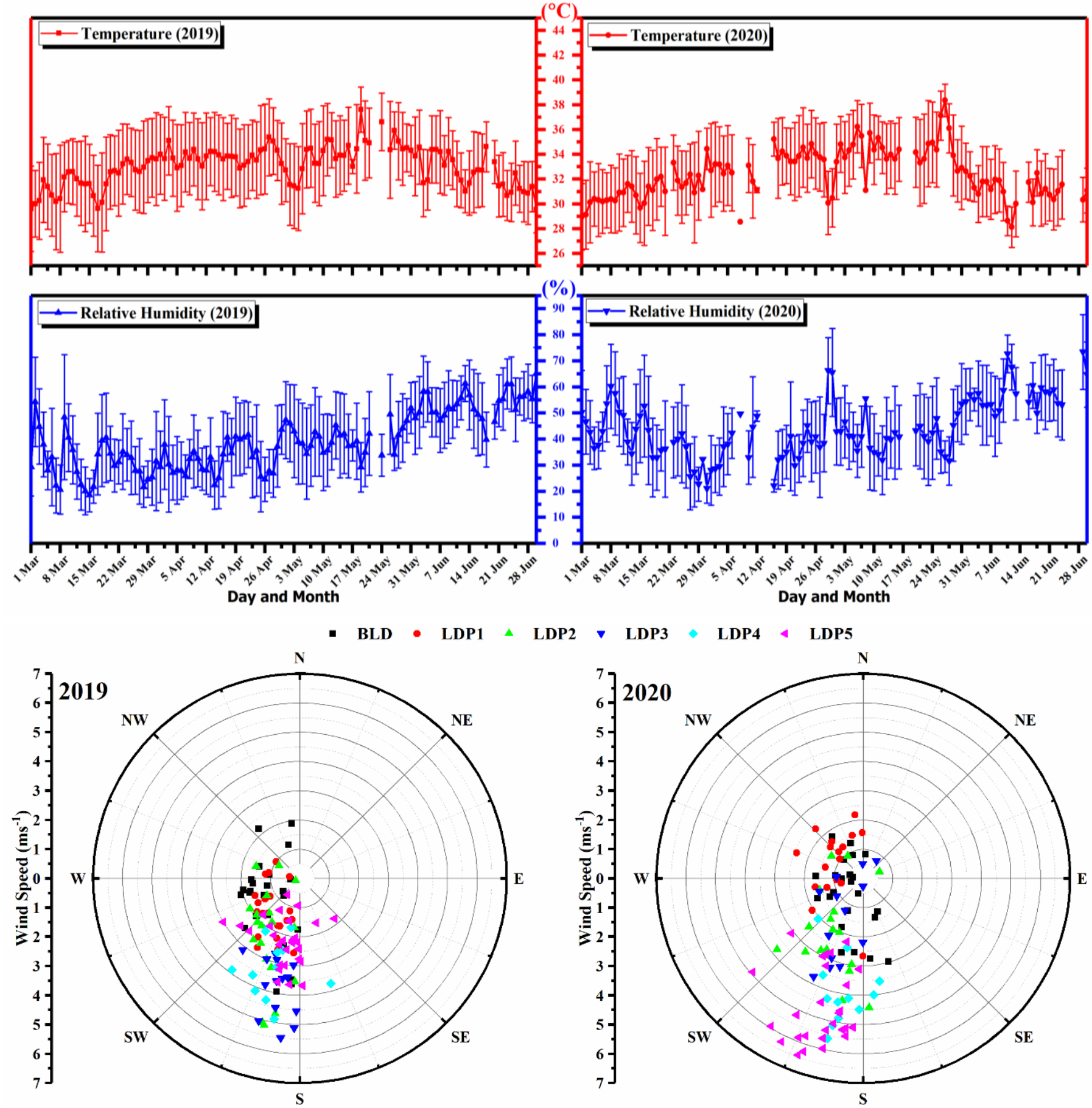

Fig. 2. Variation in daily average temperature $\left({ }^{\circ} \mathrm{C}\right)$ and relative humidity $(\%)$ along with wind rose plot showing local wind direction and distribution of wind speed $\left(\mathrm{m} \mathrm{s}^{-1}\right)$ over the study location during the months of March-June for the years 2019 and 2020.

(370, 470, 520, 590, 660, 880, and $950 \mathrm{~nm}$ ) Aethalometer (Model AE-42 of Magee Scientific, California, USA) by operating at 4 LPM of flow rate with the recording time base of 3 min interval. Before considering the analysis data, correction of the loading effect for the raw data was applied, as described in Virkkula et al. (2007). As a result, Aethalometer manufacturers have reported $\pm 5 \%$ uncertainty (Allen et al., 1999; Hansen, 2005). However, further details about measurement principles, data analysis, correction schemes were described in several earlier studies by Arnott et al. (2005); Virkkula et al. (2015, 2007); Weingartner et al. (2003); and hence not discussed more here. 


\subsection{MERRA-2 BC}

Gridded BC data $\left(0.625^{\circ} \times 0.5^{\circ}\right.$ longitude-by-latitude resolution) was retrieved from NASA's Modern Era Retrospective Analysis for Research and Applications, Version-2 (MERRA-2) re-analysis data for the measurement period (https://disc.gsfc.nasa.gov/datasets/). More detailed information about MERRA-2 is available elsewhere (Lasko et al., 2018; Qin et al., 2019). The gridded value geographically closest to a study region is selected as the comparison object for observation in this site. The black carbon aerosol transport is examined in the study using reanalysis wind data from MERRA, (Rienecker et al., 2011) reanalysis products at a grid resolution of $0.25^{\circ}$ by $0.25^{\circ}$ (http://mirador.gsfc.nasa.gov/).

In addition to a standard meteorological analysis, MERRA-2 includes an aerosol analysis, as described in Randles et al. (2017). Aerosols in MERRA-2 are simulated with a radiatively coupled version of the Goddard Chemistry, Aerosol, Radiation, and Transport model (GOCART; Chin et al., 2002; Colarco et al., 2010). GOCART treats the sources, sinks, and chemistry of 15 externally mixed aerosol mass mixing ratio tracers: dust (five noninteracting size bins), sea salt (five noninteracting size bins), hydrophobic and hydrophilic black and organic carbon (eBC and OC, respectively; four tracers), and sulfate $\left(\mathrm{SO}_{4}{ }^{2-}\right)$. Both dust and sea salt have wind speed- dependent emissions (Tandule et al., 2020). Primary sulfate and carbonaceous aerosol species are emitted principally from fossil fuel combustion, biomass burning, and biofuel consumption, with additional biogenic sources of organic carbon. Secondary sources of sulfate include chemical oxidation of sulfur dioxide gas $\left(\mathrm{SO}_{2}\right)$ and dimethyl sulfide (DMS), and we include a database of volcanic $\mathrm{SO}_{2}$ emissions and injection heights.

The hourly mean Boundary Layer Height (BLH), were obtained from ERA-5 (https://cds.climate. copernicus.eu/cdsapp\#!/dataset/reanalysis-era5-single-levels?tab=form).

\subsection{Estimating the Fossil Fuel and the Biomass Burning Component of Equivalent Black Carbon Mass Concentrations}

After applying the loading effect correction algorithm, the corrected eBC mass concentration data has been apportioned to identify the fossil fuel and biomass burning contribution to the total eBC measured. The power-law aerosol absorption coefficients $\left(\sigma_{a b s}\right)$ is proportional to $\lambda^{-\alpha}$, where $\alpha$ is the absorption Ångström exponent, and $\lambda$ is the wavelength which describes the spectral dependence of the absorption coefficient (Ångström, 1964). Consequently, for a wavelength pair, it can be derived using the following relation:

$$
\frac{\sigma_{a b s}\left(\lambda_{1}\right)}{\sigma_{a b s}\left(\lambda_{2}\right)}=\left(\frac{\lambda_{1}}{\lambda_{2}}\right)^{-\alpha}
$$

In general, coal-burning, or fossil fuel emissions, contain more eBC than other light-absorbing compounds, thus $\left(\alpha_{\mathrm{FF}} \sim 1\right)$ is also applicable to combustion of fossil fuels (Kirchstetter et al., 2004; Zotter et al., 2017). The aerosols produced by biomass combustion, on the other hand, are composed of light-absorbing organic substances and eBC, therefore $\alpha_{B B} \sim 2$ is relavant to biomass combustion (Sandradewi et al., 2008a; Zotter et al., 2017). They show strong light absorption in the near UV region of the spectrum and have a minimal contribution in the near IR region of the spectrum. With this background, Sandradewi et al. (2008a) developed a two-component Aethalometer model to obtain a qualitative measure of the relative presence of fossil fuel burning and biomass burning sources in the measured eBC. This model utilizes the light absorption by fossil fuel and woodburning sources with the basic assumption that fossil fuel and wood burning are the dominating sources of carbonaceous aerosols. Hence, the corrected $\sigma_{a b s}$ obtained from the Aethalometer is the sum of $\sigma_{a b s}^{F F}$ due to fossil fuel burning and $\sigma_{a b s}^{B B}$ due to biomass burning:

$$
\sigma_{a b s}(\lambda)=\sigma_{a b s}^{F F}(\lambda)+\sigma_{a b s}^{B B}(\lambda)
$$

Using Beer-Lambert's Law, the relation between the corrected $\sigma_{a b s}, \lambda$, and $\alpha$ for biomass burning (BB) and fossil fuel burning (FF) is: 


$$
\begin{aligned}
& \frac{\sigma_{a b s}^{F F}(370 \mathrm{~nm})}{\sigma_{a b s}^{F F}(880 \mathrm{~nm})}=\left(\frac{370}{880}\right)^{-\alpha_{F F}} \\
& \frac{\sigma_{a b s}^{B B}(370 \mathrm{~nm})}{\sigma_{a b s}^{B B}(880 \mathrm{~nm})}=\left(\frac{370}{880}\right)^{-\alpha_{B B}}
\end{aligned}
$$

For a given value of $\alpha_{F F}$ and $\alpha_{B B}$, the values for $\sigma_{a b s}^{F F}(370 \mathrm{~nm}), \sigma_{a b s}^{F F}(880 \mathrm{~nm}), \sigma_{a b s}^{B B}(370 \mathrm{~nm})$, and $\sigma_{a b s}^{B B}(880 \mathrm{~nm})$ have computed using Eqs. (2)-(4). According to this study, $\alpha_{F F}$ and $\alpha_{B B}$ values are 1, 2 respectively, which were comparable to those in the literature (Kaur et al., 2020; Kumar et al., 2020; Rajesh and Ramachandran, 2017; Vaishya et al., 2017). The contributions of fossil fuel burning (eBCFF @ $880 \mathrm{~nm}$ ) and biomass burning (eBC $\mathrm{BB}_{\mathrm{BB}} @ 880 \mathrm{~nm}$ ) to total eBC @ $880 \mathrm{~nm}$ are then derived via the corresponding mass absorption cross section (MAC) values ( $M A C_{B B}$ and $\mathrm{MAC}_{\mathrm{FF}}$, respectively):

$\mathrm{eBC} @ 880 \mathrm{~nm}=(\mathrm{eBC} F \mathrm{~F} @ 880 \mathrm{~nm})+(\mathrm{eBC} B \mathrm{BB} @ 880 \mathrm{~nm})$

$e B C_{F F}(880 \mathrm{~nm})=\frac{\sigma_{a b s}^{F F}(880 \mathrm{~nm})}{M A C_{F F}(880 \mathrm{~nm})}$

$e B C_{B B}(880 \mathrm{~nm})=\frac{\sigma_{a b s}^{B B}(880 \mathrm{~nm})}{M A C_{B B}(880 \mathrm{~nm})}$

where $\mathrm{MAC}_{\mathrm{FF}}(880 \mathrm{~nm})$ and $\mathrm{MAC}_{\mathrm{BB}}(880 \mathrm{~nm})$ is $16.6 \mathrm{~m}^{2} \mathrm{~g}^{-1}$ taken from the manufacturer (Hansen, 2005). Zotter et al. (2017) reported that there is no significant difference between $\mathrm{MAC}_{\mathrm{FF}}$ to $M A C_{B B}$ at $880 \mathrm{~nm}$. Hence the same MAC value was taken for both $M A C_{F F}$ and $M A C_{B B}$.

The limitations of the deconvolution of $\mathrm{eBC}$ to $\mathrm{eBC} C_{\mathrm{FF}}$ and $\mathrm{eBC}_{\mathrm{BB}}$ using this two-component Aethalometer model is that assuming the fossil fuel and wood burning are the dominating sources of black carbon aerosols. It is also known that wind-blown dust is one of the light-absorbing aerosols, especially absorbing UV regime (e.g., $370 \mathrm{~nm}$ in Aethalometer). This absorption by dust particles in shorter wavelengths may be difficult to identify the absorption of $\mathrm{eBC}_{\mathrm{BB}}$. One more limitation is that assumption of appropriate values for $\alpha_{F F}$ and $\alpha_{B B}$. This model is sensitive on the selected wavelength range and the prior assumed $\alpha_{F F}$ and $\alpha_{B B}$ values, as some studies used the $370-880 \mathrm{~nm}$ (Dumka et al., 2018; Kaur et al., 2020; Vaishya et al., 2017), others the 470-950 nm (Kumar et al., 2020; Sandradewi et al., 2008a, b; Zotter et al., 2017) and 370-950 nm (Rajesh and Ramachandran, 2017). Assumed $\alpha_{F F}$ ranged between $0.9-1.1$ and $\alpha_{B B}$ between $\sim 1.7-3.5$ values by (Schnaiter et al., 2003, 2005; Kirchstetter et al., 2004; Sandradewi et al., 2008a, b; Stockwell et al., 2016; Diapouli et al., 2017; Rajesh and Ramachandran, 2017; Vaishya et al., 2017; Zotter et al., 2017; Dumka et al., 2018; Kaur et al., 2020; Kumar et al., 2020).

\subsection{Estimation of the Short-wave Direct Aerosol Radiative Forcing}

The short-wave direct aerosol radiative forcing (SDARF) estimated by using the standard atmospheric model, Santa Barbara Discrete Ordinate Radiative Transfer (SBDART), which uses the discrete ordinates radiative transfer (DISORT) integration of the radiative transfer equations. Several investigators reported that this model is well suited to estimate the earth-atmosphere system's radiation budget (Aruna et al., 2016; Babu et al., 2002; Kant et al., 2020; Moorthy et al., 2009). The necessary and significant inputs for computing SDARF are spectral AOD, spectral single scattering albedo (SSA), and the scattering phase function. The AOD and eBC mass concentration data sets have been obtained from MICROTOPS sun photometer and Aethalometer during the entire phases. The SSA, Phase function, Angstrom exponent data sets were obtained from the optical properties of aerosols and clouds (OPAC) model (Hess et al., 1998).Additional inputs like surface albedo, atmospheric profiles of temperature, pressure, columnar ozone, and water vapor content are necessary to estimate shortwave radiative forcing in SBDART model. Surface reflection collected by the 8-Day, Level 3 Moderate Resolution Imaging Spectroradiometer (MODIS) 
onboard Terra (MOD09A1) and Aqua (MYD09A1) satellites at different wavelengths (0.469, $0.555,0.645,0.859,1.24,1.64$, and $2.13 \mathrm{~m}$ ) were used to calculate the surface spectral albedo. The columnar ozone and water vapour content datasets from the MICROTOPS Ozonometer have also been obtained.

Shortwave direct radiative forcing at surface, atmosphere, and top of the atmosphere and their associated heating rates $\left(\mathrm{K} \mathrm{day}^{-1}\right)$ within the atmosphere are estimated using this model. The details are furnished elsewhere (Liou, 2002). Due to the lack of sunphotometer AOD values after LDP3, the aerosol radiative forcing was estimated only for BLD, LDP1, LDP2, and LDP3. Therefore, the value reported for LD for forcing related parameters is the mean values from LDP1 to LDP3 only.

\section{RESULTS AND DISCUSSION}

\subsection{Impact of Lockdown on eBC Mass Concentration}

Fig. 3 shows the temporal change in the diurnal concentrations of $\mathrm{eBC}, \mathrm{eBC} F$, and $\mathrm{eBC} \mathrm{BB}_{\mathrm{B}}$ before and during the lockdown overlaid by atmospheric boundary layer height. It has been noticed from the figure that, irrespective of phase in lockdown, the concentration of $\mathrm{eBC}$ and $\mathrm{eBC} \mathrm{FF}_{\mathrm{F}}$ is low during the noon hours. Two prominent peaks are noticed, primary peak during the morning hours around 06:00-07:00 $\mathrm{h}$ and another less prominent peak (also known as nocturnal peak) during the evening hours around 19:00-20:00 $\mathrm{h}$ for all the periods. These diurnal variations result from the various eBC local emission sources and their strengths and atmospheric boundary layer height. In general, the height of atmospheric boundary layer $(A B L)$ starts increasing from 06:00-07:00 $\mathrm{h}$ and reaches the maximum at 14:00-15:00 $\mathrm{h}$. Later on, it starts decreasing till 19:00 $\mathrm{h}$ and tends to be invariable from 20:00 to $06: 00 \mathrm{~h}$ (Fig. 3). Chan et al. (2012) found a strong correlation between $A B L$ and incoming solar radiation. After the sunrise, a gradual increase in the radiation onset breaking the aerosols trapped in the residual layer (caused due to the night-time inversions) leading to a sharp increase in near-surface pollutants concentration (eBC: primary peak) popularly known as fumigation effect. As the day advances, due to the impact of thermal buoyancy, $A B L$ increases rapidly and redistributes aerosols vertically in deep $A B L$, making the concentration of eBC minimum at the surface level. The solar radiation tends to diminish as the day progresses, especially in the evening. After sunset, the turbulent mixing weakens, and thus ABL deforms to a shallow stable ABL near the earth's surface (Siva Kumar Reddy et al., 2021). The thermal inversions separate residual layer downwards and night-time traffic emissions leading to the nocturnal peak can be observed in the diurnal eBC cycle. The impact of $A B L$ on diurnal $e B C$ is commonly seen in all the phases, irrespective of the years. But the magnitude of the eBC concentrations varies from phase to phase in the year 2020 compared with 2019. During the year 2019, from Figs. 3(a)-3(f), the magnitude of the eBC concentrations gradually decreased due to the seasonal effect; the Indian summer monsoon. The magnitudes of eBC concentration during 2020 also follow the same trend as 2019 but with remarkable reductions. These remarkable reductions in $\mathrm{EBC}$ concentrations in the year 2020 might be attributed to the movement restrictions on all public and private vehicles imposed to control the spread of the COVID-19 pandemic, as shown in Table 1. It is interesting to note that when compared with 2019, the concentrations of eBC $\mathrm{FF}$ in the year 2020 decreased from before LD to LDP4 due to vehicular movement restrictions and an increase in the $\mathrm{eBC}_{\mathrm{BB}}$. People who live near the sampling site often cook with wood fuel and participate in a variety of farming activities, which may led to the rise in $\mathrm{eBC}_{\mathrm{BB}}$. Since the two-component Aethalometer model assumes the possible source of $\mathrm{eBC}$ is from fossil fuel combustion and biomass burning, the decrease in vehicular emission increases the share of $\mathrm{eBC}_{\mathrm{BB}}$. After LDP4, relaxations have allowed the public to resume their daily activities with minimal restrictions; hence, $\mathrm{eBC} \mathrm{FF}_{\mathrm{starts}}$ dominating over $\mathrm{eBC}_{\mathrm{BB}}$ in Anantapur. To have a better understanding of the impact of $L D$ on the surface $\mathrm{eBC}, \mathrm{eBC} F$, and $\mathrm{eBC} C_{\mathrm{BB}}$ concentrations, we herewith illustrate the mean $\mathrm{eBC}, \mathrm{eBC} \mathrm{F}_{\mathrm{F}}$, and $\mathrm{eBC}_{\mathrm{BB}}$ concentrations for each $\mathrm{LD}$ phase (derived from daily mean values) along with those relative changes between 2019 and 2020 as shown in Fig. 4. The concentration of eBC $\mathrm{FF}_{\text {in }}$ (Fig. 4(a)) 2020 shows exponential decrease from BLD $\left(1.4 \pm 0.4 \mu \mathrm{g} \mathrm{m}^{-3}\right)$ to LDP5 $\left(0.4 \pm 0.1 \mu \mathrm{g} \mathrm{m}^{-3}\right)$, whereas eBC $\mathrm{BB}$ (Fig. 4(b)) showed increase in LDP1and attained a peak value of $0.6 \pm 0.1 \mu \mathrm{g} \mathrm{m}^{-3}$ during LDP2 and started decreasing from LDP3. While considering the mean variation between BLD and DLD during 


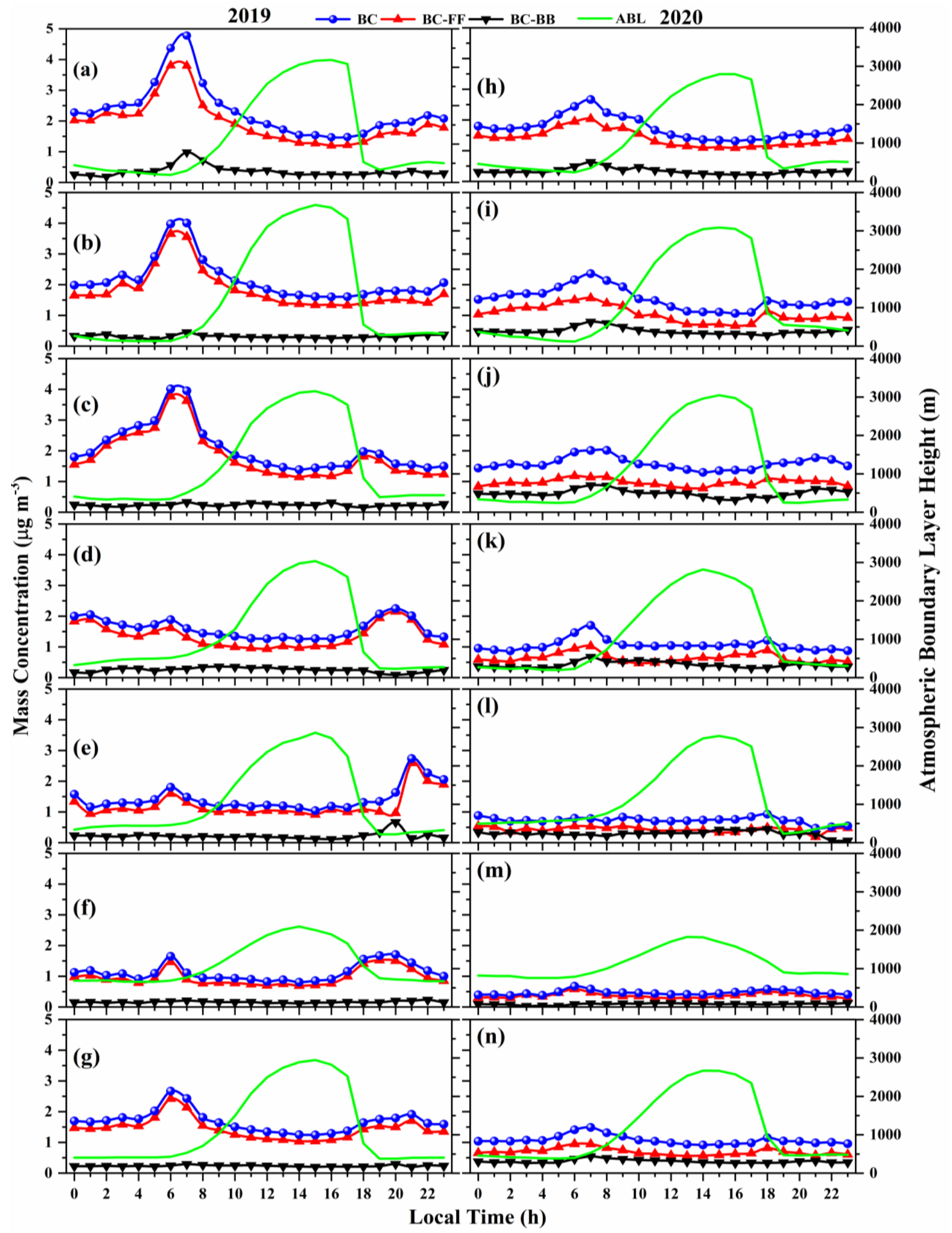

Fig. 3. Effects of lockdown on diurnal variation of equivalent black carbon (eBC-blue) mass concentrations, equivalent black carbon concentrations from fossil fuel (eBC $\mathrm{FF}-\mathrm{red}$ ), and biomass burning (eBC $\mathrm{BB}$-black) in compared with 2019 (a-g) \& 2020 ( $\mathrm{h}-$ $\mathrm{n})$ scaled to the left side. The Atmospheric boundary layer height is represented with values overlaid on line plot (Green) scaled to the right side. $\mathrm{a}$ and $\mathrm{h}$ represent before lockdown, $\mathrm{b}$ and $\mathrm{i}$-lockdown period $1, \mathrm{c}$ and j-lockdown period 2, $\mathrm{d}$ and $\mathrm{k}-$ lockdown period 3 , e and I-lockdown period 4, fand m-lockdown period 5, g and n-mean for lockdown period 1-5. Complete details and dates for the lockdowns are provided in the text. 

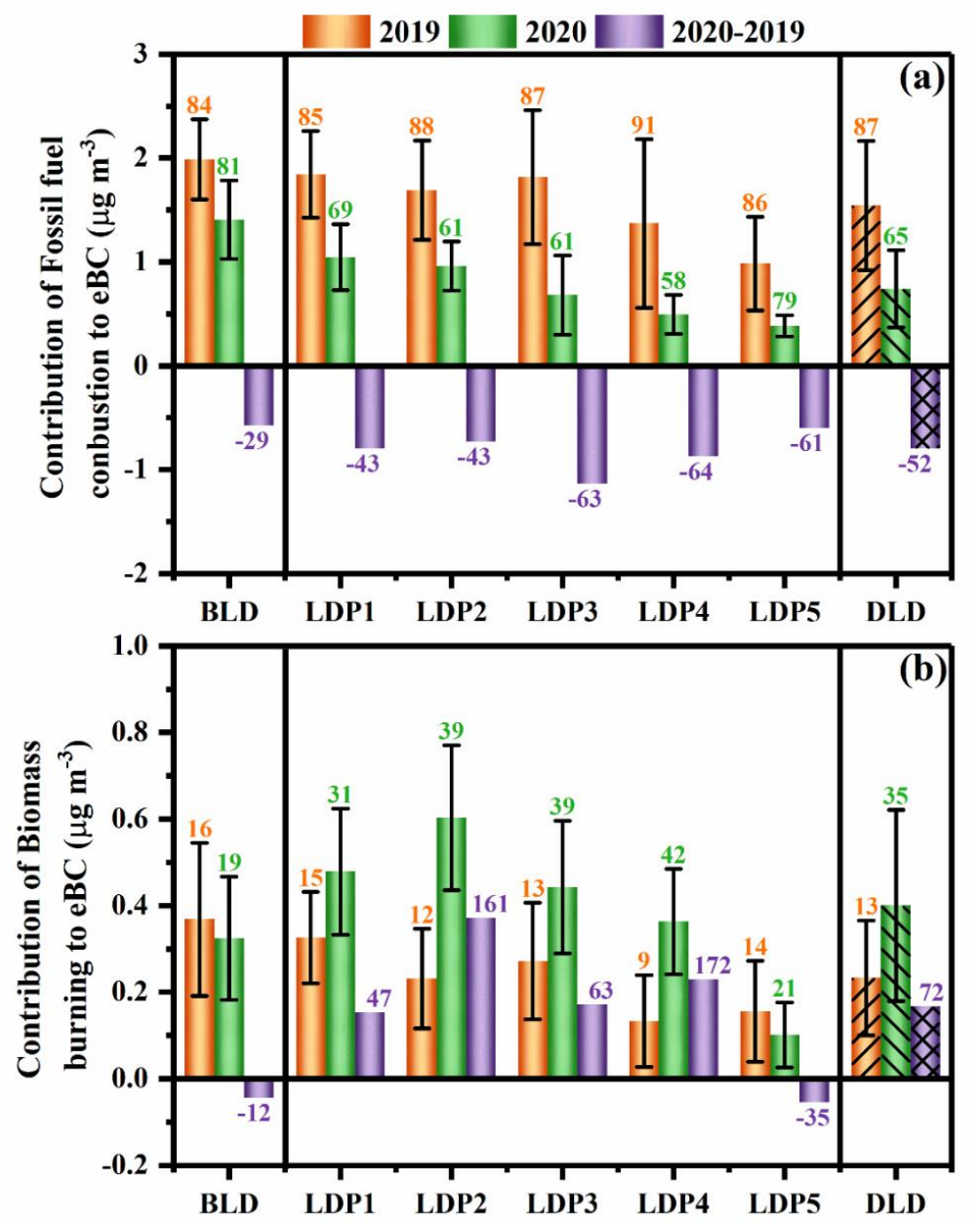

Fig. 4. Phases wise mean eBC concentration values contribution of fossil fuel combustion (a) and biomass burning (b), during in 2019 (orange) and 2020 (green) along with absolute change in respective values between 2020 and 2019 (violet). Values illustrates on top of the orange and green bars are the percentage share of with respect to the total eBC during 2019 and 2020 respectively, whereas values on violet bar are the relative change in percentage between 2020 and 2019 .

2020, it has witnessed a decrease of $33.95 \%$ in eBC and $47.19 \%$ in $\mathrm{eBC}_{\mathrm{FF}}$ with a $23.49 \%$ increase in $\mathrm{eBC}_{\mathrm{BB}}$. When compared the relative change between 2020 and 2019 , eBC $\mathrm{FF}$ always showed decreasing tendency. However, $\mathrm{eBC}_{\mathrm{BB}}$ showed an increasing tendency from LDP1 to LDP4 with relative change as high as $161 \%$ during LDP2. Moreover, to have a much clearer understanding of the impact of the unprecedented cessation of human activities during the lockdown on the regional aerosol concentration, the percentage of contribution of $\mathrm{eB} C_{\mathrm{FF}}$ and $\mathrm{eBC}_{\mathrm{BB}}$ to the total eBC for the respective phase is shown over each bar in Fig. 4. One can observe that in the year $2020, \mathrm{eBC}_{\mathrm{FF}}$ decreased from LDP1 (where nearly all services and factories were suspended, except emergency services) to LDP4. When the travel restrictions are resumed (i.e., during LDP5), eBC FF $_{\text {increased }}$ from 58\% in LDP4 to 79\% in LDP5. This pattern was not observed in the year 2019.

As shown in Table 2, the mean eBC concentration in the year 2020 during BLD, LDP1, LDP2, LDP3, LDP4, and LDP5 is much lower when compared with the same periods during 2016-2019. eBC emissions declined from $1.66 \pm 0.5$ to $1.07 \pm 0.49 \mu \mathrm{g} \mathrm{m}^{-3}(35 \%)$ during the lockdowns period over Anantapur, as compared to the same period in the previous 4 years (2016-2019). eBC emissions during BLD was decreased from $2.23 \pm 0.11$ to $1.74 \pm 0.37 \mu^{-3} \mathrm{~g} \mathrm{~m}^{-3}(22 \%)$, in LDP1 from $2.40 \pm 0.23$ to $1.54 \pm 0.36 \mu \mathrm{g} \mathrm{m}^{-3}(36 \%)$, in LDP2 from $2.05 \pm 0.13$ to $1.59 \pm 0.20 \mu \mathrm{g} \mathrm{m}^{-3}(22 \%)$, in LDP3 from $1.48 \pm 0.14$ to $1.07 \pm 0.19 \mu \mathrm{g} \mathrm{m}^{-3}(28 \%)$, in LDP4 from $1.36 \pm 0.21$ to $0.73 \pm 0.11 \mu \mathrm{g} \mathrm{m}^{-3}$ (46\%) and in LDP5 from $1.03 \pm 0.20$ to $0.47 \pm 0.07 \mu \mathrm{g} \mathrm{m}^{-3}(54 \%)$ as compared to the same period in the last 4 years. It was observed that eBC concentration, when compared with BLD 2016-19, 
there is also a noticeable decrease in the BLD phase of 2020. The government of India has imposed specific emission control measures over various industrial sectors, which have played a significant role in keeping the particulate emission in control and including that of eBC. Among those control measures, the nationwide implementation of Bharat Stage (BS) emission standards in 2000 were followed more rigorous criteria with Bharat stage IV (sulfur content of 50 ppm) in 2010 and Bharat Stage VI norms (sulfur content of just 10 ppm) in 2020 along with steps to improve the fuel quality. BS-VI norms significantly reduce contents like sulfur, lead, benzene, and much more, improves the octane/cetane number for petrol/diesel. A recent investigation on long-term variation from 2007 to 2015 of surface eBC aerosol mass concentration over India showed a significant decreasing trend with $0.07 \mu \mathrm{g} \mathrm{m}^{-3} \mathrm{y}^{-1}$ over peninsular India and $0.242 \mu \mathrm{g} \mathrm{m}^{-3} \mathrm{y}^{-1}$ overall the Indian region (Manoj et al., 2019). Similar decreasing trend of $0.02 \mu \mathrm{g} \mathrm{m}^{-3} \mathrm{month}^{-1}$ over the eastern Himalayan region between 2009 to 2015 was reported by Sarkar et al. (2019). Ravi Kiran et al. (2018) have reported $0.27 \mu \mathrm{g} \mathrm{m}^{-3}$ decrease per year over tropical site Gadanki during 2008 to 2017. There was a dramatic drop in eBC levels during the lockdown days in the year 2020 due to numerous restrictions and curfews imposed to combat the COVID-19 pandemic, which reduced anthropogenic emissions over Anantapur.

\subsection{Intercomparison of Observed and Model eBC Concentrations}

We have observed the impact of the lockdown restrictions on surface eBC concentrations. Now, we would like to look at the response of the model data during the lockdown restrictions and compare the observed and model data. We have used MERRA-2 surface mass concentration of carbon black (BCSMASS) model data for validation with ground-based observation data for our current analysis. The phase-wise mean observed and MERRA-2 BC concentrations along with bias values are shown in Fig. 5(a). It can be found that the MERRA-2 component has a clear variation for the lockdown phases in the year 2020. However, the bias between observed and MERRA-2 during 2020 is consistently low when compared with 2019 data. During 2019, the bias is always higher than 0.30 , while it is below 0.30 for 2020, irrespective of the sign. Also, the daily mean basics observed and MERRA-2 BC are well correlated in both the years with $\mathrm{R}$ values of 0.71 and 0.80 for the years 2019 and 2020, respectively as show in Fig. 5(b). In the lockdown period in 2020, MERRA-2 BC shows lower values than the corresponding period in previous year (2019). MERRA-2 satellite-based BC data also showed improved air quality at Anantapur during the lockdown. Based on the lockdown phase-wise mean, the correlation between observed and MERRA-2 are very strong, 0.94 and 0.99 for the years 2019 and 2020 (Fig. 5(c)). We can also see that the MERRA-2 has underestimated the eBC concentrations in both the years, except for few days where the concentrations are below $1 \mu \mathrm{g} \mathrm{m} \mathrm{m}^{-3}$. Therefore, it can be hypothesized that MERRA-2 BC concentrations perform better in low pollution levels than in higher pollution levels. However, Zhao et al. (2021) noticed the overestimated MERRA-2 BC concentrations in Nanjing City, where the concentration levels are much higher when compared to our study. They also found a good correlation between observed and MERRA-2 BC on monthly mean values (0.93) rather than daily mean values (0.78). Qin et al. (2019) also reported that MERRA-2 BC concentrations are overestimated (averagely $101.6 \%$ higher) than ground-based observations; however, the ground-based and MERRA- 2 mass concentrations of BC were highly correlated (0.77) over Beijing.

\subsection{Shortwave Direct Aerosol Radiative Forcing}

Table 3. provides SBDART input parameters and shortwave direct aerosol forcing for before and during lockdown phases. The positive sign in relative change denotes an increase, whereas the negative sign denotes a reduction in the AOD value. The AOD levels decreased some what from 0.39 (BLD) to 0.37 (DLD). The relative change of AOD between BDL and DLD is $-03.60 \%$ for the 2020 phases and $13.09 \%$ for the 2019 phases. When comparing the AOD values observed between 2020 and 2019 phases before LD, AOD values decreased by only $12.41 \%$. During DLD, it decrease by $28.95 \%$, a comparably substantial decline in AOD during 2020 phase. Under normal circumstances, residual crop burning and continental dust particles associated with higher wind speed are responsible for high AOD values observed during the month's March-May over the observational location (Kalluri et al., 2016). 

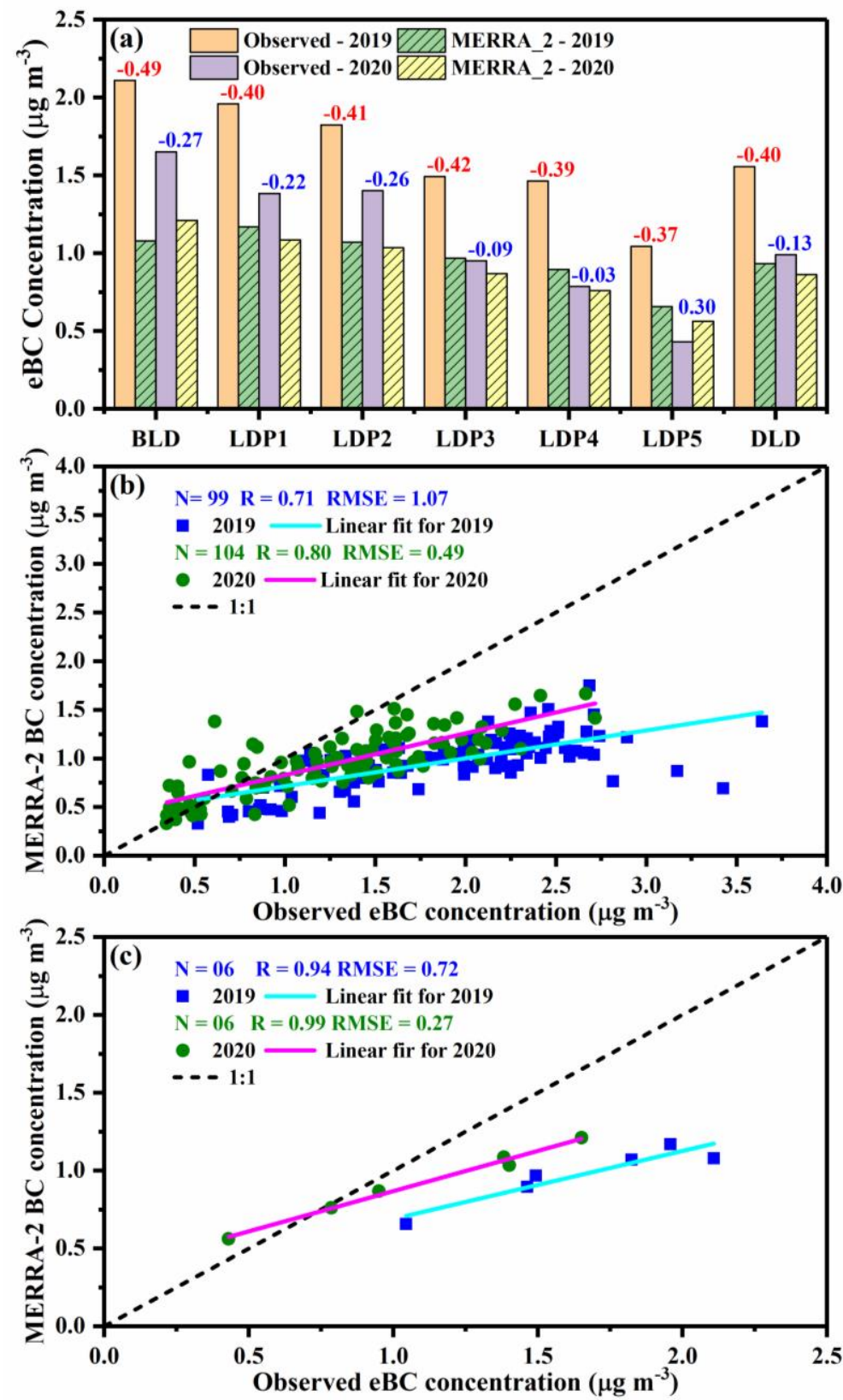

Fig. 5. Comparison of observed eBC concentrations with MERRA-2 BC concentration for various lockdown phases (a) and the values over the bar represents the bias between observed and modelled values, red for 2019 and blue for 2020. Validation of MERRA-2 BC at (b) daily level and (c) phase wise mean with observations.

A regional synthesis of $\mathrm{eBC}, \mathrm{eBC} \mathrm{FF}_{\mathrm{F}}, \mathrm{eBC} \mathrm{BB}_{\mathrm{BB}}$, and $\mathrm{AOD}$, having noted for various lockdown phases, attempted to estimate the radiative forcing due to composite and $\mathrm{EBC}$ aerosols before and during the lockdown phases. The mean picture of the phase-wise averaged SDARF due to composite aerosols at the top of the atmosphere (TOA), in the atmosphere (ATM), and at the surface (SUR) over study location is illustrated in Fig. 6 . The surface and TOA forcing due to composite aerosols increased by $11.33 \%$ from $-27.88 \mathrm{Wm}^{-2}$ (BLD) to $-24.89 \mathrm{Wm}^{-2}$ (DLD) at the surface and only $3.62 \%$ increase from $-05.47 \mathrm{Wm}^{-2}$ (BLD) to $-5.27 \mathrm{Wm}^{-2}$ (DLD) at TOA. The atmospheric forcing from BLD to DLD has been reduced from $22.41 \mathrm{Wm}^{-2}$ to $19.61 \mathrm{Wm}^{-2}$, almost a $13 \%$ reduction. Interestingly, a negative trend was observed from BLD to DLD during the 2020 phases, whereas it is positive during the 2019 phases. The high surface forcing might be due to large scattering particles inhibiting the solar radiation reaching the earth's surface. 
Table 3. SBDART input parameters and shortwave direct aerosol forcing for before and during lockdown phases.

\begin{tabular}{|c|c|c|c|c|c|c|c|}
\hline & & \multirow[t]{2}{*}{ Phases } & \multirow[t]{2}{*}{2019} & \multirow[t]{2}{*}{2020} & \multirow{2}{*}{$\begin{array}{l}\text { \% change } \\
\text { (2019 vs. 2020) }\end{array}$} & \multicolumn{2}{|c|}{$\begin{array}{c}\text { \% change } \\
\text { (BLD vs. DLD) }\end{array}$} \\
\hline & & & & & & 2019 & 2020 \\
\hline \multirow{2}{*}{\multicolumn{2}{|c|}{ Aerosol Optical Depth }} & BLD & 0.44 & 0.39 & -12.41 & 13.09 & -03.62 \\
\hline & & DLD & 0.50 & 0.37 & -28.95 & & \\
\hline \multirow{2}{*}{\multicolumn{2}{|c|}{ Single Scattering Albedo }} & BLD & 0.93 & 0.95 & 1.52 & 00.45 & -01.60 \\
\hline & & DLD & 0.94 & 0.93 & -0.53 & & \\
\hline \multirow{2}{*}{\multicolumn{2}{|c|}{$\begin{array}{l}\text { Total Columnar Ozone } \\
\text { (DU) }\end{array}$}} & BLD & 247.77 & 265.00 & 6.72 & 08.51 & 02.78 \\
\hline & & DLD & 269.79 & 272.47 & 0.99 & & \\
\hline \multirow{2}{*}{\multicolumn{2}{|c|}{ Water Vapor $(\mathrm{cm})$}} & BLD & 1.65 & 2.17 & 27.31 & 26.28 & 07.68 \\
\hline & & DLD & 2.15 & 2.35 & 8.73 & & \\
\hline \multirow{6}{*}{$\begin{array}{l}\text { Composite aerosol } \\
\text { Radiative forcing } \\
\left(\mathrm{W} \mathrm{m}^{-2}\right)\end{array}$} & Surface & BLD & -31.66 & -27.88 & -12.71 & 08.25 & -11.33 \\
\hline & & DLD & -34.39 & -24.89 & -32.05 & & \\
\hline & Atmosphere & BLD & 26.71 & 22.41 & -17.52 & 04.75 & -13.31 \\
\hline & & DLD & 28.01 & 19.61 & -35.26 & & \\
\hline & Top of Atmosphere & BLD & -04.95 & -05.47 & 09.92 & 25.18 & -03.62 \\
\hline & & DLD & -06.38 & -05.27 & -18.95 & & \\
\hline \multirow{6}{*}{$\begin{array}{l}\text { eBC aerosol Radiative } \\
\text { forcing }\left(\mathrm{W} \mathrm{m}^{-2}\right)\end{array}$} & Surface & BLD & -10.63 & -08.58 & -21.30 & -21.11 & -28.71 \\
\hline & & DLD & -08.60 & -06.43 & -28.90 & & \\
\hline & Atmosphere & BLD & 14.45 & 11.19 & -25.44 & -21.94 & -26.56 \\
\hline & & DLD & 11.59 & 08.56 & -30.03 & & \\
\hline & Top of Atmosphere & BLD & 03.82 & 02.60 & -37.83 & -24.30 & -19.73 \\
\hline & & DLD & 02.99 & 02.14 & -33.35 & & \\
\hline \multirow{6}{*}{$\begin{array}{l}\text { eBC contribution to } \\
\text { total forcing (\%) }\end{array}$} & Surface & BLD & 33.58 & 30.79 & 08.65 & 29.23 & 17.52 \\
\hline & & DLD & 25.01 & 25.83 & -03.22 & & \\
\hline & Atmosphere & BLD & 54.09 & 49.93 & 08.01 & 26.62 & 13.37 \\
\hline & & DLD & 41.39 & 43.67 & -05.37 & & \\
\hline & Top of Atmosphere & BLD & 77.07 & 47.59 & 47.30 & 48.73 & 16.14 \\
\hline & & DLD & 46.87 & 40.48 & 14.63 & & \\
\hline
\end{tabular}

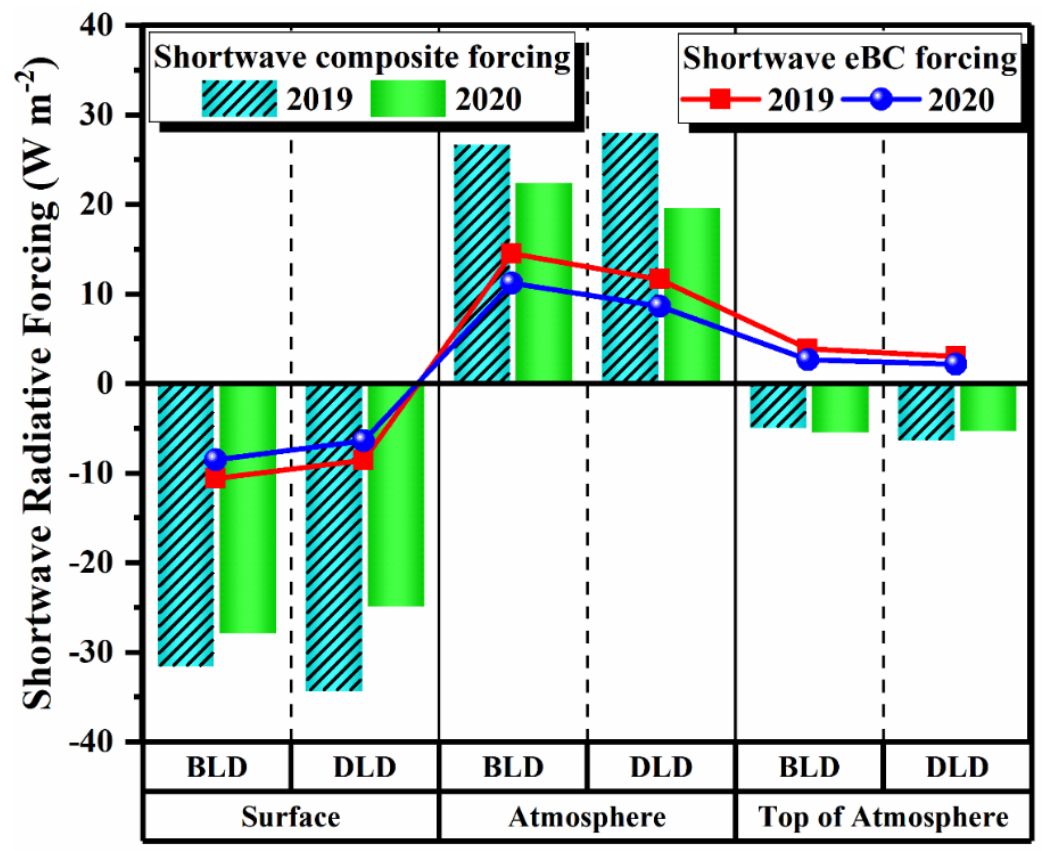

Fig. 6. The shortwave direct aerosol radiative forcing due to composite (bar) and eBC (symbol and line) aerosols, the light green bar, and blue sphere line plot representing the 2020 phases and the cyan bar with patterns and red squares plot represents 2019 phases for comparison. 
The SDARF is due to eBC represents the difference between the SDARF for aerosols with and without the $\mathrm{eBC}$ component. To estimate the forcing due to eBC alone, optical parameters for aerosols have been deduced again, keeping $B C$ concentration equal to zero and constructed columnar AOD for the eBC-free atmosphere from OPAC. The surface forcing due to the eBC component is $-08.58 \mathrm{Wm}^{-2}$ during $\mathrm{BLD}$ and $-06.43 \mathrm{Wm}^{-2}$ during $\mathrm{LD}$, which contributes almost $25-30 \%$ contribution to the composite aerosol forcing. The eBC forcing at TOA is 2.60 before LD and 2.14 during LD, with a $40-47 \%$ contribution to the composite forcing. Interestingly, the amount of energy trapped in the atmosphere due to eBC is 11.19 before LD and 8.56 during LD. i.e., eBC contributes almost $43-50 \%$ to the composite forcing. When compared the 2020 phases with the 2019 phases, the eBC contribution to the composite forcing in the 2020 phases is reduced to $60 \%$, $50 \%$, and $33 \%$ at SUR, ATM, and TOA concerning the 2019 phases. The positive forcing at the TOA arises due to the absorption by black carbon in the atmosphere, which also leads to a net cooling effect (negative forcing) at the surface. During LD, the composite atmospheric heating rate was significantly lower $\left(0.55 \mathrm{~K} \mathrm{day}^{-1}\right)$ than $\mathrm{BLD}\left(0.63 \mathrm{~K} \mathrm{day}^{-1}\right)$, i.e., $13 \%$ reduction. On the other hand, the equivalent heating rate was slightly greater $\left(0.79 \mathrm{~K} \mathrm{day}^{-1}\right)$ than $\mathrm{BLD}\left(0.75 \mathrm{~K} \mathrm{day}^{-1}\right)$, implying a $5 \%$ increase in the 2019 phases. Due to eBC over Anantapur, the atmosphere's overall heating rateis $0.31 \mathrm{~K} \mathrm{day}^{-1}$ before LD and is reduced to $0.24 \mathrm{~K} \mathrm{day}^{-1}$ during LD. During the lockdown phases, the heating rates due to composite aerosols decreased by $13 \%$, whereas it is $25 \%$ due to eBC aerosols. It indicates that the restrictions on vehicular emission and anthropogenic activities during lockdown phases have significantly influenced the $\mathrm{eBC}$ aerosols concentrations rather than composite aerosols.

The magnitude of the aerosol radiative forcing depends not only on the aerosol composition but also on the column abundance. Consequently, it is a strong function of the AOD. The aerosol forcing efficiency is generally defined as the rate at which the atmosphere is "forced" per unit of aerosol optical depth, increasing as the AOD increases. To understand the impact of lockdown on forcing efficiency over Anantapur we also analyzed the aerosol forcing efficiency in different lockdown phases. Before LD, the net TOA and SUR forcing efficiency were about -14.18 and $-72.30 \mathrm{Wm}^{-2} \tau^{-1}$, respectively. For the DLD, the corresponding values were about -14.16 and $66.89 \mathrm{Wm}^{-2} \tau^{-1}$, respectively.

\section{CONCLUSIONS}

The effect of unprecedented cessation of human activities during the COVID-19 pandemic was studied using in-situ based observations of eBC aerosols and their implications to short wave radiative properties from $01^{\text {st }}$ March to $30^{\text {th }}$ June 2020 over a semi-arid station in Southern India. The salient outcomes from the present investigation are as below:

1. The mean eBC mass concentration before and during LD was found to be $1.74 \mu \mathrm{g} \mathrm{m}^{-3}$, and $1.12 \mu \mathrm{g} \mathrm{m}^{-3}$, i.e., decreases by more than $\sim 35 \%$ during LD than BLD due to the reduction of anthropogenic activities and meterology.

2. Due to the restricted vehicular emission during the lockdown period, the contribution of fossil fuel burning to total eBC showed a distinct variation between BLD (81\%) and DLD (64\%).

3. A good correlation between observed and MERRA-2 BC concentrations is found with a correlation coefficient greater than 0.70 .

4. During LD, the net forcing at the top of the atmosphere and the surface due to composite aerosols varied from -4.52 to $-6.19 \mathrm{Wm}^{-2}$, and -22.91 to $-29.35 \mathrm{Wm}^{-2}$, respectively, and net forcing in the atmosphere changes in the range 17.27 to $23.16 \mathrm{Wm}^{-2}$.

5. The contribution of $\mathrm{eBC}$ alone to the composite forcing within the atmosphere during LD (BLD) was found to be $43.64 \%$ (49.93\%), respectively.

6. The restrictions on vehicular emission during the lockdown phases have significantly influenced the $\mathrm{eBC}$ rather than composite aerosols. The heating rate justifies this with a $13 \%$ reduction due to composite and a $25 \%$ reduction due to eBC aerosols.

\section{ACKNOWLEDGEMENTS}

The authors wish to thank the Indian Space Research Organization, Bangalore for the financial support provided by ISRO-GBP under the ARFI and NOBLE Project. 


\section{REFERENCES}

Allen, G.A., Lawrence, J., Koutrakis, P. (1999). Field validation of a semi-continuous method for aerosol black carbon (aethalometer) and temporal patterns of summertime hourly black carbon measurements in southwestern PA. Atmos. Environ. 33, 817-823. https://doi.org/10. 1016/S1352-2310(98)00142-3

Ångström, A. (1964). The parameters of atmospheric turbidity. Tellus 16, 64-76 https://doi.org/10.1111/j.2153-3490.1964.tb00144.x

Arnott, W.P., Hamasha, K., Moosmüller, H., Sheridan, P.J., Ogren, J.A. (2005). Towards aerosol light-absorption measurements with a 7-wavelength aethalometer: Evaluation with a photoacoustic instrument and 3-wavelength nephelometer. Aerosol Sci. Technol. 39, 17-29. https://doi.org/10.1080/027868290901972

Aruna, K., Kumar, T.V.L., Murthy, B.V.K., Babu, S.S., Ratnam, M.V., Rao, D.N. (2016). Short wave Aerosol Radiative Forcing estimates over a semi urban coastal environment in south-east India and validation with surface flux measurements. Atmos. Environ. 125, 418-428. https://doi.org/10.1016/j.atmosenv.2015.08.085

Babu, S.S., Satheesh, S.K., Moorthy, K.K. (2002). Aerosol radiative forcing due to enhanced black carbon at an urban site in India. Geophys. Res. Lett. 29, 1880. https://doi.org/10.1029/2002G L015826

Chan, L.U., Deng, Q.H., Liu, W.W., Huang, B.L., Shi, L.Z. (2012). Characteristics of ventilation coefficient and its impact on urban air pollution. J. Cent. South Univ. Technol. 19, 615-622. https://doi.org/10.1007/s11771-012-1047-9

Chauhan, A., Singh, R.P. (2020). Decline in $\mathrm{PM}_{2.5}$ concentrations over major cities around the world associated with COVID-19. Environ. Res. 187, 109634. https://doi.org/10.1016/j.envres. 2020.109634

Diapouli, E., Kalogridis, A.C., Markantonaki, C., Vratolis, S., Fetfatzis, P., Colombi, C., Eleftheriadis, K. (2017). Annual variability of black carbon concentrations originating from biomass and fossil fuel combustion for the suburban aerosol in Athens, Greece. Atmosphere 8, 234. https://doi.org/10.3390/atmos8120234

Dumka, U.C., Kaskaoutis, D.G., Tiwari, S., Safai, P.D., Attri, S.D., Soni, V.K., Singh, N., Mihalopoulos, N. (2018). Assessment of biomass burning and fossil fuel contribution to black carbon concentrations in Delhi during winter. Atmos. Environ. 194, 93-109. https://doi.org/10.1016/ j.atmosenv.2018.09.033

Fan, C., Li, Z., Li, Y., Dong, J., Van Der A, R., De Leeuw, G. (2021). Variability of $\mathrm{NO}_{2}$ concentrations over China and effect on air quality derived from satellite and ground-based observations. Atmos. Chem. Phys. 21, 7723-7748. https://doi.org/10.5194/acp-21-7723-2021

Gogoi, M.M., Babu, S.S., Moorthy, K.K., Bhuyan, P.K., Pathak, B., Subba, T., Chutia, L., Kundu, S.S., Bharali, C., Borgohain, A., Guha, A., Kumar De, B., Singh, B., Chin, M. (2017). Radiative effects of absorbing aerosols over northeastern India: Observations and model simulations. J. Geophys. Res. 122, 1132-1157. https://doi.org/10.1002/2016JD025592

Gogoi, M.M., Tandule, C.R., V, J., Kompalli, S.K., Nair, V.S., Gopal, K.R., Babu, S.S. (2019). Spatial gradient of aerosol mass concentrations and size distributions over southeastern Arabian Sea and equatorial Indian Ocean during ICARB-2018. Atmos. Environ. 213, 727-738. https://doi.org/10.1016/j.atmosenv.2019.06.038

Gopal,R.K., Arafath, S.M., Lingaswamy, A.P., Balakrishnaiah, G., Pavan Kumari, S., Uma Devi, K. Siva Kumar Reddy, N., Raja Obul Reddy, K., Penchal Reddy, M., Reddy, R.R., Suresh Babu, S. (2014). In-situ measurements of atmospheric aerosols by using Integrating Nephelometer over a semi-arid station, southern India. Atmos. Environ. 86, 228-240. https://doi.org/10.1016/j.at mosenv.2013.12.009

Gopal, R.K., Arafath, S.M., Balakrishnaiah, G., Raja Obul Reddy, K., Siva Kumar Reddy, N., Lingaswamy, A.P., Pavan Kumari, S., Uma Devi, K., Reddy, R.R., Suresh Babu, S. (2015). Columnar-integrated aerosol optical properties and classification of different aerosol types over the semi-arid region, Anantapur, Andhra Pradesh. Sci. Total Environ. 527-528, 507-519. https://doi.org/10.1016/j.scitotenv.2015.04.086

Gopal, R.K., Obul Reddy, K.R., Balakrishnaiah, G., Arafath, S.M.D., Kumar Reddy, N.S., Rao, T.C., 
Reddy, T.L., Reddy, R.R. (2016). Regional trends of aerosol optical depth and their impact on cloud properties over Southern India using MODIS data. J. Atmos. Sol. Terr. Phys. 146, 38-48. https://doi.org/10.1016/j.jastp.2016.05.005

Gopal, R.K., Balakrishnaiah, G., Arafath, S.M., Raja Obul Reddy, K., Siva Kumar Reddy, N., Pavan Kumari, S., Raghavendra Kumar, K., Chakradhar Rao, T., Lokeswara Reddy, T., Reddy, R.R., Nazeer Hussain, S., Vasudeva Reddy, M., Suresh Babu, S., Mallikarjuna Reddy, P. (2017). Measurements of scattering and absorption properties of surface aerosols at a semi-arid site, Anantapur. Atmos. Res. 183, 84-93. https://doi.org/10.1016/j.atmosres.2016.08.016

Hansen, A.D.A. (2005). The Aethalometer--User Manual. Magee Sci. Company, California, USA.

Hess, M., Koepke, P., Schult, I. (1998). Optical properties of aerosols and clouds: The software package OPAC. Bull. Am. Meteorol. Soc. 79, 831-844. https://doi.org/10.1175/15200477(1998)079<0831:OPOAAC>2.0.CO;2

Hussain, N.S., Chakradhar Rao, T., Balakrishnaiah, G., Rama Gopal, K., Raja Obul Reddy, K., Siva Kumar Reddy, N., Lokeswara Reddy, T., Pavan Kumari, S., Ramanjaneya Reddy, P., Ramakrishna Reddy, R. (2018). Investigation of black carbon aerosols and their characteristics over tropical urban and semi-arid rural environments in peninsular India. J. Atmos. Sol. Terr. Phys. 167, 4857. https://doi.org/10.1016/j.jastp.2017.10.010

Ichoku, C., Levy, R., Kaufman, Y.J., Remer, L.A., Li, R.R., Martins, V.J., Holben, B.N., Abuhassan, N., Slutsker, I., Eck, T.F., Pietras, C. (2002). Analysis of the performance characteristics of the fivechannel Microtops II Sun photometer for measuring aerosol optical thickness and precipitable water vapor. J. Geophys. Res. 107, AAC 5-1-AAC 5-17. https://doi.org/10.1029/2001JD001302

IPCC (2013). Climate Change 2013: The Physical Science Basis. Contribution of Working Group I to the Fifth Assessment Report of the Intergovernmental Panel on Climate Change. Stocker, T.F., Qin, D., Plattner, G.K., Tignor, M., Allen, S.K., Boschung, J., Nauels, A., Xia, Y., Cambridge University Press, Cambridge, United Kingdom and New York, NY, USA.

Jacobson, M.Z. (2001). Global direct radiative forcing due to multicomponent anthropogenic and natural aerosols. J. Geophys. Res. 106, 1551-1568. https://doi.org/10.1029/2000JD900514

Jain, S., Sharma, T. (2020). Social and travel lockdown impact considering coronavirus disease (COVID-19) on air quality in megacities of India: Present benefits, future challenges and way forward. Aerosol Air Qual. Res. 20, 1222-1236. https://doi.org/10.4209/aaqr.2020.04.0171

Kalluri, R.O.R., Gugamsetty, B., Kotalo, R.G., Nagireddy, S.K.R., Tandule, C.R., Thotli, L.R., Rajuru Ramakrishna, R., Surendranair, S.B. (2016). Direct radiative forcing properties of atmospheric aerosols over semi-arid region, Anantapur in India. Sci. Total Environ. 566-567, 1002-1013. https://doi.org/10.1016/j.scitotenv.2016.05.056

Kalluri, R.O.R., Balakrishnaiah, G., Rama Gopal, K., Reddy, K.S.N., ChakradharRao, T., Lokeswara Reddy, T., NazeerHussain, S., Reddy, V.M., Reddy, R.R., Babu,S.S. (2017). Seasonal variation of near surface black carbon and satellite derived vertical distribution of aerosols over a semiarid station in India. Atmos. Res. 184, 77-87. https://doi.org/10.1016/j.atmosres.2016.09.003

Kalluri, R.O.R., Gugamsetty, B., Kotalo, R.G., Thotli, L.R., Tandule, C.R., Akkiraju, B. (2020a). Longterm (2008-2017) analysis of atmospheric composite aerosol and black carbon radiative forcing over a semi-arid region in southern India: Model results and ground measurement. Atmos. Environ. 240, 117840. https://doi.org/10.1016/j.atmosenv.2020.117840

Kalluri, R.O.R., Zhang, X., Bi, L., Zhao, J., Yu, L., Kotalo, R.G. (2020b). Carbonaceous aerosol emission reduction over Shandong province and the impact of air pollution control as observed from synthetic satellite data. Atmos. Environ. 222, 117150. https://doi.org/10.1016/j.atmosen v.2019.117150

Kalluri, R.O.R., Gugamsetty, B., Tandule, C.R., Kotalo, R.G., Thotli, L.R., Rajuru, R.R., Palle, S.N.R. (2021). Impact of aerosols on surface ozone during COVID-19 pandemic in southern India: A multi-instrumental approach from ground and satellite observations, and model simulations. J. Atmos. Sol. Terr. Phys. 212, 105491. https://doi.org/10.1016/j.jastp.2020.105491

Kang, S., Zhang, Y., Qian, Y., Wang, H. (2020). A review of black carbon in snow and ice and its impact on the cryosphere. Earth Sci. Rev. 210, 103346. https://doi.org/10.1016/j.earscirev.20 20.103346

Kant, Y., Shaik, D.S., Mitra, D., Chandola, H.C., Babu, S.S., Chauhan, P. (2020). Black carbon aerosol quantification over north-west Himalayas: Seasonal heterogeneity, source apportionment and radiative forcing. Environ. Pollut. 257, 113446. https://doi.org/10.1016/j.envpol.2019.113446 
Kaur, P., Srinivasan, P., Dhar, P., Kumar De, B., Guha, A. (2020). Study of spectral characteristics of black carbon from biomass burning and source apportionment over Agartala in the northeastern India. Environ. Sci. Pollut. Res. 27, 16584-16598. https://doi.org/10.1007/s1135 6-020-08094-8

Kirchstetter, T.W., Novakov, T., Hobbs, P.V (2004). Evidence that the spectral dependence of light absorption by aerosols is affected by organic carbon. J. Geophys. Res. 109, D21208. https://doi.org/10.1029/2004JD004999

Kumar, R.R., Soni, V.K., Jain, M.K. (2020). Evaluation of spatial and temporal heterogeneity of black carbon aerosol mass concentration over India using three year measurements from IMD BC observation network. Sci. Total Environ. 723, 138060. https://doi.org/10.1016/j.scitotenv.2 020.138060

Lasko, K., Vadrevu, K.P., Nguyen, T.T.N. (2018). Analysis of air pollution over Hanoi, Vietnam using multi-satellite and MERRA reanalysis datasets. PLoS One 13, e0214628. https://doi.org/10.13 71/journal. pone.0214628

Li, L., Che, H., Derimian, Y., Dubovik, O., Schuster, G.L., Chen, C., Li, Q., Wang, Y., Guo, B., Zhang, X. (2020). Retrievals of fine mode light-absorbing carbonaceous aerosols from POLDER/PARASOL observations over East and South Asia. Remote Sens. Environ. 247, 111913. https://doi.org/10. 1016/j.rse.2020.111913

Lingaswamy, A.P., Arafath, S.M., Balakrishnaiah, G., Rama Gopal, K., Siva Kumar Reddy, N., Raja Obul Reddy, K., Reddy, R.R., Chakradhar Rao, T. (2017). Observations of trace gases, photolysis rate coefficients and model simulations over semi-arid region, India. Atmos. Environ. 158, 246258. https://doi.org/10.1016/j.atmosenv.2017.03.048

Liou, K.N. (Ed.) (2002). Inside Front Cover, in: International Geophysics, Academic Press, p. ifc1. https://doi.org/10.1016/S0074-6142(13)62908-3

Moorthy, K.K., Nair, V.S., Babu, S.S., Satheesh, S.K. (2009). Spatial and vertical heterogeneities in aerosol properties over oceanic regions around india: Implications for radiative forcing. Q. J. R. Meteorol. Soc. 135, 2131-2145. https://doi.org/10.1002/qj.525

Petzold, A., Ogren, J.A., Fiebig, M., Laj, P., Li, S.M., Baltensperger, U., Holzer-Popp, T., Kinne, S., Pappalardo, G., Sugimoto, N., Wehrli, C., Wiedensohler, A., Zhang, X.Y. (2013). Recommendations for reporting black carbon measurements. Atmos. Chem. Phys. 13, 8365-8379. https://doi.org/10.5194/acp-13-8365-2013

Prasad, R., Perappadan, B.S., Shelar, J., Koshy, J. (2020). The Pandemic Notebook. The Hindu. pp. $1-19$.

Qin, W., Zhang, Y., Chen, J., Yu, Q., Cheng, S., Li, W., Liu, X., Tian, H. (2019). Variation, sources and historical trend of black carbon in Beijing, China based on ground observation and MERRA-2 reanalysis data. Environ. Pollut. 245, 853-863. https://doi.org/10.1016/j.envpol.2018.11.063

Rajesh, T.A., Ramachandran, S. (2017). Characteristics and source apportionment of black carbon aerosols over an urban site. Environ. Sci. Pollut. Res. 24, 8411-8424. https://doi.org/10.1007/s 11356-017-8453-3

Randles, C.A., da Silva, A.M., Buchard, V., Colarco, P.R., Darmenov, A., Govindaraju, R., Smirnov, A., Holben, B., Ferrare, R., Hair, J., Shinozuka, Y., Flynn, C.J. (2017). The MERRA-2 aerosol reanalysis, 1980 onward. Part I: System description and data assimilation evaluation. J. Clim. 30, 6823-6850. https://doi.org/10.1175/JCLI-D-16-0609.1

Reddy, K.R.O., Zhang, X., Bi, L. (2019). Seasonal aerosol variations over a coastal city, Zhoushan, China from CALIPSO observations. Atmos. Res. 218, 117-128. https://doi.org/10.1016/j.atmo sres.2018.11.011

Rienecker, M.R. (2011). MERRA-NASA's Modern-Era Retrospective analysis for research and applications. J. Clim. 24, 3624-3648. https://doi.org/10.1175/JCLI-D-11-00015.1

Sandradewi, J., Prévôt, A.S.H., Szidat, S., Perron, N., Alfarra, M.R., Lanz, V.A., Weingartner, E., Baltensperger, U. (2008a). Using aerosol light absorption measurements for the quantitative determination of wood burning and traffic emission contributions to particulate matter. Environ. Sci. Technol. 42, 3316-3323. https://doi.org/10.1021/es702253m

Sandradewi, J., Prévôt, A.S.H., Weingartner, E., Schmidhauser, R., Gysel, M., Baltensperger, U. (2008b). A study of wood burning and traffic aerosols in an Alpine valley using a multiwavelength Aethalometer. Atmos. Environ. 42, 101-112. https://doi.org/10.1016/j.atmosenv. 2007.09.034 
Sarfraz, M., Shehzad, K., Shah, S.G.M. (2020). The impact of COVID-19 as a necessary evil on air pollution in India during the lockdown. Environ. Pollut. 266, 115080. https://doi.org/10.1016/ j.envpol.2020.115080

Schnaiter, M., Horvath, H., Mohler, O., Naumann, K. (2003). UV-VIS-NIR spectral optical properties of soot and soot-containing aerosols. J. Aerosol Sci. 34, 1421-1444. https://doi.org/10.1016/ S0021-8502(03)00361-6

Schnaiter, M., Linke, C., Möhler, O., Naumann, K.H., Saathoff, H., Wagner, R., Schurath, U., Wehner, B. (2005). Absorption amplification of black carbon internally mixed with secondary organic aerosol. J. Geophys. Res. 110, D19204. https://doi.org/10.1029/2005JD006046

Shalini, V., Narasimhulu, K., Raja Obul Reddy, K., Balakrishnaiah, G., Rama Gopal, K., Lokeswara Reddy, T., Chakradhar Rao, T., Elijabetthamma, B., Manjunatha, C., Ramakrishna Reddy, R. (2020). Chemical characterization and source identification of particulate matter at Ballari $\left(15.15^{\circ} \mathrm{N}, 76.93^{\circ} \mathrm{E}\right)$, Karnataka over Southern Indian region. J. Atmos. Sol. Terr. Phys. 200, 105192. https://doi.org/10.1016/j.jastp.2020.105192

Sharma, S., Zhang, M., Anshika, Gao, J., Zhang, H., Kota, S.H. (2020). Effect of restricted emissions during COVID-19 on air quality in India. Sci. Total Environ. 728, 138878. https://doi.org/10.10 16/j.scitotenv.2020.138878

Siva Kumar Reddy, N., Kiran Kumar, N.V.P., Rama Gopal, K., Balakrishnaiah, G., Rajaobul Reddy, K. (2021). Characteristics of atmospheric surface layer during winter season over Anantapur $\left(14.62^{\circ} \mathrm{N}, 77.65^{\circ} \mathrm{E}\right)$, a semi-arid location in peninsular India. J. Atmos. Sol. Terr. Phys. 216, 105554. https://doi.org/10.1016/j.jastp.2021.105554

Stockwell, C.E., Christian, T.J., Goetz, J.D., Jayarathne, T., Bhave, P. V., Praveen, P.S., Adhikari, S., Maharjan, R., DeCarlo, P.F., Stone, E.A., Saikawa, E., Blake, D.R., Simpson, I.J., Yokelson, R.J., Panday, A.K. (2016). Nepal Ambient Monitoring and Source Testing Experiment (NAMaSTE): Emissions of trace gases and light-absorbing carbon from wood and dung cooking fires, garbage and crop residue burning, brick kilns, and other sources. Atmos. Chem. Phys. 16, 11043-11081. https://doi.org/10.5194/acp-16-11043-2016

Tandule, C.R., Kalluri, R.O.R., Gugamsetty, B., Kotalo, R.G., Thotli, L.R., Rajuru, R.R., Vaddin, S. (2020). Decadal climatology of the spatial and vertical distributions of tropospheric aerosol over the Arabian Sea based on satellite observations. Int. J. Climatol. 40, 4676-4689. https://doi.org/10.1002/joc.6482

Thomas, A., Sarangi, C., Kanawade, V.P. (2019). Recent increase in winter hazy days over central India and the Arabian sea. Sci. Rep. 9, 17406. https://doi.org/10.1038/s41598-019-53630-3

Vaishya, A., Singh, P., Rastogi, S., Babu, S.S. (2017). Aerosol black carbon quantification in the central Indo-Gangetic Plain: Seasonal heterogeneity and source apportionment. Atmos. Res. 185, 13-21. https://doi.org/10.1016/j.atmosres.2016.10.001

Virkkula, A., Mäkelä, T., Hillamo, R., Yli-Tuomi, T., Hirsikko, A., Hämeri, K., Koponen, I.K. (2007). A simple procedure for correcting loading effects of aethalometer data. J. Air Waste Manage. Assoc. 57, 1214-1222. https://doi.org/10.3155/1047-3289.57.10.1214

Virkkula, A., Chi, X., Ding, A., Shen, Y., Nie, W., Qi, X., Zheng, L., Huang, X., Xie, Y., Wang, J., Petäjä, T., Kulmala, M. (2015). On the interpretation of the loading correction of the aethalometer. Atmos. Meas. Tech. 8, 4415-4427. https://doi.org/10.5194/amt-8-4415-2015

Weingartner, E., Saatho, H., Schnaiter, M., Streit, N. (2003). Absorption of light by soot particles: Determination of the absorption coe cient by means of aethalometers. J. Aerosol Sci. 34, 14451463. https://doi.org/10.1016/S0021-8502(03)00359-8

Zhao, Q., Zhao, W., Bi, J., Ma, Z. (2021). Climatology and calibration of MERRA-2 PM2.5 components over China. Atmos. Pollut. Res. 12, 357-366. https://doi.org/10.1016/j.apr.2020. 11.016

Zotter, P., Herich, H., Gysel, M., El-Haddad, I., Zhang, Y., Mocnik, G., Hüglin, C., Baltensperger, U., Szidat, S., Prévôt, A.S.H. (2017). Evaluation of the absorption Ångström exponents for traffic and wood burning in the Aethalometer-based source apportionment using radiocarbon measurements of ambient aerosol. Atmos. Chem. Phys. 17, 4229-4249. https://doi.org/10.519 4/acp-17-4229-2017 